\title{
Bioaccumulation Potentials of Momordica charantia L. Medicinal Plant Grown in Lead Polluted Soil under Organic Fertilizer Amendment
}

\author{
Ojo Michael OSENI ${ }^{1 *}$, Omotola Esther DADA², Adekunle Ajayi ADELUSI ${ }^{1}$ \\ 'Obafemi Awolowo University, Faculty of Science, Department of Botany, Ile-Ife, Nigeria; osenimichaelola@yahoo.com (*corresponding author); aadelusi@oanife.edu.ng \\ ${ }_{2}^{2} J o s e p h$ Ayo Babalola University, College of Natural Sciences, Department of Biological Sciences (Ecology and Environmentalstudies unit), Ikeji-Arakeji, Nigeria; \\ estherdada10@yahoo.com
}

\begin{abstract}
This study investigated bioaccumulation factors and translocation factors of lead $(\mathrm{Pb})$ by $M$. charantia so as to ascertain the bioaccumulation potentials of this medicinal plant. The elemental deposition of $\mathrm{Pb}$ were also assessed in order to compare the concentration of $\mathrm{Pb}$ present in plant tissues with the maximum permissible limits of $10 \mathrm{ppm}$ recommended by WHO (1998, 2007). The experiment was a factorial combination of one heavy metal $(\mathrm{Pb})$ at five levels of concentrations $(0,200,400,800$ and $1,000 \mathrm{ppm})$ in a completely randomized design, replicated three times, with one medicinal plant species and two levels ( 0 and $9.4 \mathrm{~g}$ ) of organic fertilizer (OBD- Plus). The seedlings were transplanted from nursery to experimental pots at the rate of one seedling per pot and grown for 10 weeks, after which the plants were harvested and dried for the analysis of $\mathrm{Pb}$ concentration both in soil and plant tissues using Atomic Absorption Spectrophotometry (AAS). The highest bioaccumulation factor for roots was 0.42 under fertilizer amendment, whereas the highest bioaccumulation factor for shoots was 0.26 under the same treatment. The highest transfer factor of $M$. charantia was 0.6 . The results showed that $M$. charantia is a good phytostabilizer of $\mathrm{Pb}$ component. The highest lead deposition in the roots, which was $40 \%$ higher than in the shoots concentration, was above the safe limit; therefore this might pose health risks to human if consumed as herbal medicine.
\end{abstract}

Keywords: Atomic Absorption Spectrophotometer, bioaccumulation factor, Pb, phytoextraction, phytostabilizer, translocation factor

\section{Introduction}

Since the dawn of history, man has relied so much on medicinal plants for health and food needs (Nwachukwu et al., 2010). The traditional uses of medicinal plants for curing and preventing illnesses, including the promotion of both physical and spiritual wellbeing among human beings have become paramount (Idu and Onyibe, 2007). Medicinal herbs are consumed all over the world. The use of medicinal herbs to relieve and treat many human diseases is increasing around the world due to their mild features and low side effects (Yap et al., 2010). A World Health Organization (WHO, 2007) survey indicated that about $70-80 \%$ of the world population relies on non-conventional medicine, mainly of herbal sources, in their primary health care. This report revealed that medicinal plants and their trace elements play an important role in the treatment of diseases (Chan, 2003).

Heavy metals are known to have the ability to bioaccumulate and thus disrupt functions of vital organs and glands in the human body, affecting brain, kidney and liver (Suranjana and Minas, 2009). Medicinal plants can be contaminated by these heavy metals via roots uptake or by direct deposition of contaminants from the atmosphere onto plant surfaces (Dzomba et al., 2012). WHO (2005) recommended that herbal drugs should not be used without qualitative and quantitative analysis of their heavy metal contents. Moreover, medicinal plants which form the raw materials for finished products must be checked for the presence of different contaminant such as heavy metals, pesticides, fungi and micro-organisms.

In an attempt to control pollution of medical plants by heavy metal, WHO regulated maximum permissible limits of heavy metals like arsenic, cadmium and lead to 0.1, 0.3, $10 \mathrm{ppm}$, respectively (WHO, 1998, 2007). Ingestion of high concentration of heavy metals such as chromium, cadmium and lead can cause reduced growth rate, hepatic and renal impairment (Blowes, 2002).

According to Khan et al. (2008), medicinal herbs are easily contaminated during growth, development and processing. This shows that soil environment in which medicinal plants grow is one of the major pathway through which heavy metal components enters into the plants tissues and thus into food chain.

Accumulation of metals in plants is highly dependent on their availability in soil (Rahimi et al., 2013). These plants can uptake the heavy metals that are found in soil, water or air (Mclanghin et al., 1999). Soil to plant transfer is one of the key processes of human exposure to heavy metals through the food chain. Heavy metals uptake from soil via the root and direct deposition of contaminants from the atmosphere on plant surfaces can lead to plant contamination by heavy metals (Zhuang et al., 2009). In addition, accumulation of these metals in the edible parts of medical plants has potential health 
290

implication on humans and animals (Lokhande and Sathe, 2003). Heavy metals are the most harmful and insidious pollutants because of their non-biodegradable nature and their potential to cause adverse effects at certain levels of exposure and absorption (Sharma and Chhetri, 2005). Once the heavy metals get accumulated as contaminants, they can neither be destroyed nor altered by chemical or physical means (Kabata-Pendias, 2010). Since there is an inextricable link between the plants and the soil environment, there is a great need to monitor the bioaccumulation potentials of medicinal plants as they grow on polluted soils (Dada and Awotoye, 2013).

The use of synthetic chelates has been shown to dramatically stimulate the potential for $\mathrm{Pb}$ accumulation in plants. Compounds such as EDTA, DTPA (Diethylene triamine pentaacetate) and low molecular weight organic acid such as oxalic acid and citric acid, prevent $\mathrm{Pb}$ precipitation and keep the metals as soluble chelate- $\mathrm{Pb}$ complexes available for uptake into roots and transport within plants. Ethylene diaminetetraacetate (EDTA) is probably the chelating agent that is most efficient at increasing the solubility of heavy metals in soil solutions from the solid phase (Blaylock $e t$ al., 1997; Huang et al., 1997). EDTA application solubilizes about $80 \%$ of the total soil metal, thereby making them available for phytoextraction. Adding organic fertilizer could improve soil structure, and then promote desorption of $\mathrm{Pb}$ out from the soil surface, thus enhance its bioavailability. Zhang (2009) found that continuously adding organic fertilizer would inhibit the activity of $\mathrm{Pb}, \mathrm{Hg}$ and $\mathrm{Cd}$. This is because continuously adding the organic fertilizer increases the soil organic matter and thus inhibit the activity of metals.

One of the greatest concerns of human health is caused by $\mathrm{Pb}$ contamination. Lead $(\mathrm{Pb})$ is a major anthropogenic pollutant and has accumulated in different terrestrial and aquatic ecosystems (Verma et al, 2003). In year 2000, EPA (Environmental Protection Agency) enlisted lead as a potential carcinogenic element in nature. Inhalation and ingestion are the two major routes of exposure, and the effects from both are the same (Henry, 2000). Lead accumulates in the body, which may lead to poisoning or even death. The gastrointestinal tract, kidneys and central nervous system are also affected by the presence of lead. Children exposed to lead are at risk of impaired development, lower IQ, shortened attention span, hyperactivity and metal deterioration, with children under the age of six being at a more substantial risk (Henry, 2000). Adults usually experience decreased reaction time, loss of memory, nausea, insomnia, anorexia and weakness of joints when exposed to $\mathrm{Pb}$ (Henry, 2000).

In this study, the medicinal plant Momordica charantia L. was studied for its curative effects. Momordica charantia L. is commonly known as bitter melon, papilla, bitter gourd, salsamino, corrila, karela, hanzal, assorossie, ampalaya, nigauri, goya, pare, kho gua, sora, balsam apple, pear or balsamina, and several other common names (Taylor, 2002). In South-West Nigeria, it is called "Ejirin”" (Sofowora, 1993). It is an economically important medicinal plant belonging to the family Cucurbetaceae. The immature fruits are eaten as vegetables and are a good source of vitamin $\mathrm{C}$, vitamin $\mathrm{A}$, phosphorus and iron (Sultana and Bari, 2003; Paul et al., 2009). The bitter flavour is due to the alkaloid momordicine produced in its fruits and leaves (Paul and Raychandhuri, 2010). Fruits and seeds of bittergourd possess medicinal properties such as anti-HIV, anti-ulcer, antiinflammatory, anti-leukemic, antimicrobial, antitumor and antidiabetic property (Taylor, 2002). The fruits and leaves of $M$. charantia have medicinal potential in treatment of many diseases such as piles, leprosy, jaundice, diabetes, snake-bite and have also been found to have vermifuge and antioxidant properties (Jonathan et al., 2012). It also contains cytotoxic proteins (ribosome inactivating) such as momorcharin and momordin (Santhi et al., 2011). In many parts of the world, especially poor countries, this may be one of the therapies available to treat diabetic patients.

Hence, the essence of this study was designed to: (1) investigate the bioaccumulation factor of lead contamination in Momordica charantia; (2) determine the translocation factors of $\mathrm{Pb}$ in the medicinal plant under experiment; and (3) compare the concentration of the $\mathrm{Pb}$ accumulated by the plant with the recommended concentration accepted by the international organizations.

\section{Materials and Methods}

Study area

The study was carried out under a screen house in the Biological Gardens of Obafemi Awolowo University campus, Ile -Ife, Nigeria. The town Ile-Ife lies within latitude $7^{0} 30^{\prime} \mathrm{N}-7^{0} 35^{\prime}$ $\mathrm{N}$ and longitude $4^{0} 30^{\prime}-4^{0} 35^{\prime} \mathrm{E}$; the latitude of the study area is $7^{0} 31^{\prime} \mathrm{N}$ and longitude is $4^{0} 31^{\prime} \mathrm{E}$. Osun state is geographically located in moderately hot, humid tropical climatic zone of South-western Nigeria. There are two distinct seasons in the area, namely the rainy season, which lasts from March to October, and the dry season, which last for the rest of the year, that is October to March. The mean value for temperature is about $30^{\circ} \mathrm{C}$ during the dry season, while during rainy season, low temperatures are experienced between July and August with the minimum temperature as low as $24^{\circ} \mathrm{C}$.

\section{Collection of materials}

Samples of top soils were randomly collected from the depth of $0-20 \mathrm{~cm}$ where anthropogenic activities were minimal. The soil samples were air dried for a week. The air dried soil samples were sieved using $2 \mathrm{~mm}$ mesh gauze to remove debris and stones. Seven-liter plastic pots of $23 \mathrm{~cm}$ diameter were used for the experiment. In order to allow aeration, the plastic pots were perforated at the base using soldering iron.

Viable (correctly identified) seeds of $M$. charantia were obtained from the wild.

\section{Experimental design}

The experiment was a factorial combination of one heavy metal $(\mathrm{Pb})$ at five levels of concentrations $(0,200,400,800$ and $1,000 \mathrm{ppm}$ ) laid in a completely randomized design and replicated three times, with one medicinal plant and two levels $(0$ and $9.4 \mathrm{~g}$ ) of organic fertilizer (OBD-Plus) at the rates of $0 \mathrm{~kg}$ and $40 \mathrm{~kg}$ per hectare.

\section{Pre-plantingoperations}

The physical and chemical parameters of the soil samples used for the experiment were determined using standard methods.

A nursery bed was prepared for Momordica charantia and the seeds were planted at $2 \mathrm{~cm}$ depth. The nursery bed was watered to field capacity.

\section{Preparation of lead solution and the amendment}

Heavy metal used in the experiment was Lead $(\mathrm{Pb})$ and Lead (11) nitrate $\left\{\mathrm{Pb}\left(\mathrm{NO}_{3}\right)_{2}\right\}$ salt served as the source of the lead $(\mathrm{Pb})$ used. A known weight of Lead (11) nitrate with respect to each 
concentration of $0,200,400,800$ and 1,000 ppm was dispensed into one litre of volumetric flask, allowed to cool and shaked vigorously. The resultant solution was dispensed in a sterile bottle, allow to set and ready for use. Organic fertilizer OBD-Plus with nitrogen $(\mathrm{N})$ content of $0.95 \%$ was used to augment the soil at the concentration of 0 and $9.4 \mathrm{~g}$ at the rate of $0 \mathrm{~kg}$ and $40 \mathrm{~kg}$ respectively per hectare.

\section{Pollution of soil}

Each pot was labeled using permanent maker with respect to the concentration of heavy metal and fertilizer applied. Plastic trays were placed under each pot for the collection of excess water to prevent loss of pollutants. After the application of pollutant, the pots were left for one week to allow for equilibration. Thereafter, organic fertilizer was applied to augment the soil.

\section{Transplanting intopolluted soil}

Two weeks after germination of the seeds in the nursery bed, the seedlings with a good growth and uniform height were selected and transplanted to each experimental pot at the rate of one seedling per pot. Wetting was done every day to field capacity.

\section{Postplantingoperations}

Harvesting

All the plants were carefully harvested and soil samples were taking from each pot. Plant roots were rinsed under running tap water, while water droplets were removed using blotting papers. Each plant was separated into root and shoot.

\section{Laboratory analysis}

Soilheavy metal analysis

Soil extracted for heavy metals analysis was carried out using the IITA (1982) methodology. $10 \mathrm{~g}$ of each soil sample were placed in a conical flask. One hundred milliliters of a mixture of $10 \mathrm{ml} \mathrm{HNO}_{3}, 5 \mathrm{ml} \mathrm{HCL}$, made up to $250 \mathrm{ml}$ with distilled water were added to each soil sample. This was shaken for 30 minutes on a reciprocal shaker and filtered through Whatman filter paper. Analysis of the soil extract for $\mathrm{Pb}$ was carried out using Spectronic 20 Absorption spectrophotometer.

\section{Heavy metal analysis in plant samples}

1.0 gof the powdered sample was weighed into a conical flask in triplicate. $10 \mathrm{~cm}^{3}$ of the digestion mixture (a mixture of sulphuric acid, perchloric acid and nitric acid in ratio 1:4:40 by volume) was added and left to stand overnight. Thereafter, the flask was heated at $70^{\circ} \mathrm{C}$ for about 40 minutes and then the heat was increased to $120^{\circ} \mathrm{C}$. The mixture turned black after a while and the digestion was complete when the solution became clear with appearance of white fumes (Audu and Lawal, 2005). The digest was diluted with $10 \mathrm{~cm}^{3}$ of water and boiled for 15 minutes. This was then allowed to cool, transferred into $50 \mathrm{~cm}^{3}$ volumetric flasks and diluted to the mark with water. The sample solution was then filtered through a filter paper into a screw capped polyethylene bottle and stored for heavy metal determination using Spectronic 20 Atomic Absorption Spectrophotometer with a digital read out system.

\section{Statistical analysis}

Separate analysis of variance for the heavy metal concentration at different treatments and mean separation by Fisher's LSD at $\mathrm{P}<0.05$ were calculated. All analyses were carried out using SAS version 9.2.

\section{Bioaccumulation factor and Translocation factor}

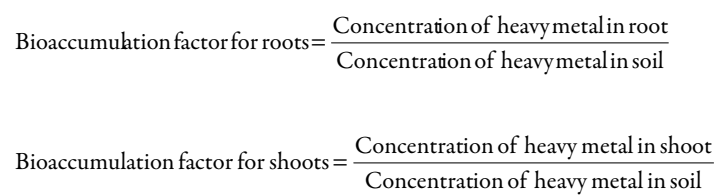

Bioaccumulation factor for the whole plant $=\frac{\text { Concentration of heavy metal in plant }}{\text { Concentration of heavy metal in soil }}$

Transfer factor $=\frac{\text { Concentration of heavy metal in shoot }}{\text { Concentration of hevy }}$

Concentration of heavy metal in root

\section{Results and Discussion}

Physical and chemical properties of the soil used in the experiment

The physical and chemical characteristics of the soil used within the screen house study were presented in Table 1 . The textural classification of the soil was loamy sand. The $\mathrm{pH}$ in 1:1 soil to water was 5.8 for the topsoil, indicating a slightly acidic soil condition. The organic carbon content of the soil was 40.10 $\mathrm{g} / \mathrm{kg}$, while nitrogen, phosphorus and potassium values were 3.20 $\mathrm{g} / \mathrm{kg}, 10.4 \mathrm{mg} / \mathrm{kg}$ and $2,605 \mathrm{mg} / \mathrm{kg}$ respectively. The calcium $(\mathrm{Ca})$ and magnesium $(\mathrm{Mg})$ contents were $31.0 \mathrm{mg} / \mathrm{kg}$ and $2,432.5 \mathrm{mg} / \mathrm{kg}$ respectively, with lead concentration of 0.098 ppm.

Bioaccumulation factor (BCF) of Momordica charantia with and without fertilizer application

The bioaccumulation factors for $M$. charantia were shown in Table 2. The bioaccumulation factor for shoots of $M$. charantia (BCFsh) without fertilizer application ranged between 0.010.18 , while under fertilizer application the BCFsh ranged between 0.03 to 0.26 , with $44 \%$ increase when compared with the control. Across the various pollution strengths, as the level of lead concentration increased, the BCFsh in the root and shoot increased also. Although, the highest shoots' bioaccumulation factor was reported in $M$. charantia treated with organic fertilizer.

The bioaccumulation factor for roots of $M$. charantia (BCFr) ranged between 0.03-0.32 without fertilizer application and between 0.02-0.42 under fertilizer application (Table 2). Similarly, as the level of lead concentration increased, the bioaccumulation factor for roots increased for both treatments, with and without fertilizer application. The bioaccumulation factor for roots was higher under fertilizer application.

The bioaccumulation factor for the whole plant (BCFplt) ranged between 0.04-0.50 without fertilizer application and between 0.02-0.68 under fertilizer application (Table 2). The bioaccumulation factor for the whole plant also increased as the level of lead concentration increased, with the highest value recorded under fertilizer application.

A plant's ability to accumulate metals from soils can be estimated using the bioaccumulation factor $(\mathrm{BCF})$, which is defined as the ratio of metal concentration in the plant to that in soil. In this experiment, under organic fertilizer application, the highest bioaccumulation factors in the root and shoot were 0.42 and 0.26 respectively. These result showed that lead accumulated in the roots more than in shoots. This report was in line with the findings of Parsa et al. (2007) and Cho-Ruk (2006). Also it is in 
292

Table 1. Physical and chemical characteristics of soil used for the experiment

\begin{tabular}{|c|c|}
\hline Characteristics & Value \\
\hline $\mathrm{pH}$ in water $\left(\mathrm{H}_{2} \mathrm{O}\right)$ & 5.8 \\
\hline Organic carbon $(\mathrm{g} / \mathrm{kg})$ & 4.10 \\
\hline Nitrogen $(\mathrm{g} / \mathrm{kg})$ & 3.30 \\
\hline Clay & $6.8 \%$ \\
\hline Silt & $4.0 \%$ \\
\hline Sand & $89 \%$ \\
\hline Phosphorus (mg/kg) & 10.4 \\
\hline $\mathrm{Ca}^{2+}$ & 31.0 \\
\hline $\mathrm{Mg}^{2+}(\mathrm{mg} / \mathrm{kg})$ & 2432.5 \\
\hline $\mathrm{K}^{+}$ & 2605 \\
\hline $\mathrm{Na}^{+}$ & 272.5 \\
\hline Lead (ppm) & 0.098 \\
\hline
\end{tabular}

Table 2. Bioaccumulation and translocation factors for Momordica charantia

\begin{tabular}{cccccc}
\hline \multirow{2}{*}{$\begin{array}{c}\text { Lead concentration } \\
(\mathrm{ppm})\end{array}$} & \multicolumn{4}{c}{ Bioaccumulation and translocation factor } \\
\cline { 2 - 6 } & 0 & BCFsh & BCFr & BCFplt & TF \\
\hline FN & 0.01 & 0.03 & 0.04 & 0.33 \\
& 400 & 0.06 & 0.16 & 0.23 & 0.33 \\
& 800 & 0.08 & 0.19 & 0.25 & 0.49 \\
& 1000 & 0.17 & 0.28 & 0.45 & 0.55 \\
$\mathrm{~F}$ & 0.18 & 0.32 & 0.50 & 0.60 \\
& 200 & 0.01 & 0.02 & 0.02 & 0.09 \\
& 400 & 0.11 & 0.27 & 0.37 & 0.39 \\
& 800 & 0.12 & 0.23 & 0.34 & 0.52 \\
& 1000 & 0.21 & 0.42 & 0.63 & 0.50 \\
\hline
\end{tabular}

Legend: BCFsh- Bioaccumulation factor for shoot, BCFr- Bioaccumulation factor for root, BCFplt- Bioaccumulation factor for whole plant, TF- transfer factor FN- No fertilizer, F- Fertilizer

Table 3. Elemental deposition oflead (ppm) in the shoots of Momordica charantia

\begin{tabular}{cccc}
\hline \multirow{2}{*}{$\begin{array}{c}\text { Lead concentration } \\
\text { (ppm) }\end{array}$} & \multicolumn{2}{c}{$\begin{array}{c}\text { Concentration of lead (ppm) in Momordica } \\
\text { charantia }\end{array}$} \\
\cline { 2 - 4 } NF & 0 & Shoot & Roots \\
\hline & 200 & $0.00^{\mathrm{e}}$ & $28.00 \mathrm{e}$ \\
& 400 & $9.42^{\mathrm{d}}$ & $48.63 \mathrm{c}$ \\
& 800 & $23.61^{\mathrm{c}}$ & $179.20 \mathrm{~b}$ \\
$\mathrm{~F} 1$ & $98.00^{\mathrm{b}}$ & $191.90 \mathrm{a}$ \\
& 1000 & $115.37^{\mathrm{a}}$ & $0.00 \mathrm{e}$ \\
& 0 & $0.00^{\mathrm{e}}$ & $37.22 \mathrm{~d}$ \\
& 200 & $14.70^{\mathrm{d}}$ & $63.48 \mathrm{c}$ \\
& 400 & $32.80^{\mathrm{c}}$ & $221.20 \mathrm{~b}$ \\
& 800 & $110.70^{\mathrm{b}}$ & $251.30 \mathrm{a}$ \\
\hline
\end{tabular}

Legend: NF- No fertilizer, F- Fertilizer; Means with the same letters of superscrip within the column are not significantly different at $\mathrm{P}<0.05$

agreement with the work of Mojiri (2011) who studied the potential of corn (Zea mays) for phytoremediation of soil contaminated with cadmium and lead, using EDTA for the bioavalability of heavy metals. Adejumo et al. (2011) studied insitu remediation of heavy metal contaminated soil using Mexican sunflower (Tithonia diversifolia) and cassava waste as composts with favorable results. However, Wang et al. (2007) gave a contrary report when using Bidens maximowicziana to phytoremediate lead under EDTA-enhanced innovation. This may be due to the fact that $B$. maximowicziana have been reported to accumulate high concentration of lead in its tissues as a good hyperaccumulator of lead (Nie et al., 2004).

Studies on $\mathrm{Pb}$ uptake in plants have demonstrated that roots have the ability to take up significant quantities of $\mathrm{Pb}$, while simultaneously greatly restricting its translocation to above ground parts (Lane and Martins, 1977). Majority of lead is easily taken up by plants from the soil and accumulated in root, while only a small fraction is translocated upward to the shoots (Patra et al., 2004). This may be because passive transport of ions occurred in the root which was directly exposed to the ionic environment in soil. This may extend to the endodermis and not beyond because of the casparian strip. According to Mojiri (2011), the capacity of soil to adsorb lead increases with increasing $\mathrm{pH}$, cation exchange capacity (CEC), organic carbon content, soil/water Eh (redox potential) and phosphate levels. In natural setting, lead hyperaccumulation has not been documented. Some ways to induce $\mathrm{Pb}$ solubility are to decrease soil $\mathrm{pH}$ and lower its organic matter, because $\mathrm{Pb}$ binds to organic material in the soil (McBride, 1994; Sharma and Dubey, 2005).

The highest bioaccumulation factor of the whole plant obtained in the hereby experiment was 0.68 in Momordica charantia. None of the bioaccumulation factors was higher than 1 , meaning that Momordica charantia is a good phytostabilizer of lead.

\section{Transferfactor}

The transfer factors for M. charantia ranged from 0.31 without fertilizer application and 0.09-0.60 under fertilizer application as shown in Table 2. These results revealed that fertilizer amendment enhanced the mobility index of $\mathrm{Pb}$ from the root to the shoot of the medicinal plant.

Ability of plant to translocate metals from the roots to the shoots was measured using the transfer factor (TF). Enrichment occurs when a contaminant taken up by a plant is not degraded rapidly, resulting in an accumulation in the plant. The process of phytoextraction generally requires the translocation of heavy metals to easily harvestable plant parts, e.g. shoots. By comparing bioaccumulation factor and transfer factor, one can compare the ability of different plants in taking up metals from soil and translocating them to the shoots. Tolerant plants tend to restrict soil-root and root-shoot transfers, and therefore have much less accumulation in their biomass, while hyperaccumulators actively take up and translocate metals into their aboveground biomass. Plants exhibiting transfer factor and particularly bioaccumulation factor values less than 1 are unsuitable for phytoextraction (Fitz and Wenzel, 2002), but they can be insidious if the belowground biomass that is phytostabilizing the metal components is consumed as source of herbal medicine (Dada and Awotoye, 2013).

The highest transfer factor of the experiment was 0.6 , both without and with fertilizer application. All the transfer factors were less than 1 , showing low translocation of $\mathrm{Pb}$ from their roots to shoots. This can be attributed to the effect of $\mathrm{Pb}$ toxicity. Tang $e t$ al. (2009) indicated that in Arabis paniculata, for the range of 9$267 \mu \mathrm{M}$ of $\mathrm{Pb}$ concentration, when the transfer factor was below 1. Similarly, Aiyesanmi et al. (2012) recounted the effect of lead toxicity when studying lead accumulation effects in Siam weed (Chromolaena odorata), node weed (Synedrella nodiflora) and water leaf (Talinum triangulare) as potential phytoremediators.

\section{Elemental depositions oflead (Pb) in M. charantia}

Across the tested medicinal species, with and without fertilizer application, the bioaccumulation concentration of $\mathrm{Pb}$ in the roots and shoots of $M$. charantia increased as the level of $\mathrm{Pb}$ concentration increased in the soil as shown in Table 3. The Pb concentration in the shoots ranged between $0.00-115.37 \mathrm{ppm}$ without fertilizer application and between 0.00-151.00 ppm 
under fertilizer application. Whereas the heavy metal deposition in the roots of $M$. charantia ranged between 0.00-191.90 ppm without fertilizer application and between 0.00-251.30 ppm under fertilizer application (Table 3 ). The roots of $M$. charantia had the highest bioaccumulation concentration of lead.

Momordica charantia showed high absorption and $\mathrm{Pb}$ uptake. Furthermore, all the tested plants showed a direct relationship between $\mathrm{Pb}$-uptake and the level of lead contamination. This shows that at higher pollution level $M$. charantia has the phytoremediation ability to accumulate lead from the soil through passive transport especially under organic fertilizer inducement.

As anticipated from previous studies involving other species (Blaylock et al., 1997; Aiyesanni et al., 2012), higher absorption of $\mathrm{Pb}$ was recorded for plants grown on soil treated with organic fertilizer, because organic fertilizer had been known not to only to enhance the bioavailability of $\mathrm{Pb}$, but also improved plant establishment and growth under pollution stress. This is because organic fertilizer serves as a good source of nitrogen and phosphorus nutrition for plants.

Comparing the lead concentration $(9.42 \mathrm{ppm}$ to $151.00 \mathrm{ppm}$ ) in the shoots with the recommended permissible limit of $10 \mathrm{ppm}$ set by $\mathrm{FAO} / \mathrm{WHO}$ (1976), the lead deposition in Momordica charantia were close and high above the safe limit recommended. Similarly, the highest lead deposition in the roots, which was $40 \%$ higher than in the shoots concentration, was also above the safe limit recommended by WHO (2007).

\section{Conclusions}

M. charantia as medicinal plant used in the current experiment showed a significantly high absorption of lead. It could also be observed that treatment of the soil with organic fertilizer enhanced the uptake of $\mathrm{Pb}$ in the plants by increasing the bioavailability of $\mathrm{Pb}$ in soil solution. The medicine plant exhibit characteristics of a phytostabilizer because the transfer factors were less than 1. This however, poses a health risk to human if consumed, since the levels of $\mathrm{Pb}$ were high in the shoots, which are the parts mostly used for herbal medicine.

\section{Acknowledgements}

The authors sincerely appreciate the diligence, patience, advice and support of industrious supervisor, Prof. A. A. Adelusi of Department of Botany, Faculty of Science, Obafemi Awolowo University, Ile-Ife, Nigeria; his guidance, constructive criticisms and encouragement contributed immeasurably to the success of this study. The authors also appreciate Dr. (Mrs.) O.E. Dada, Department of Biological Sciences (Ecology and Environmental studies unit), College of Natural Sciences, Joseph Ayo Babalola University, IkejiArakeji, Nigeria and Mr. Okunlola Lanre, Biological Sciences Department, Osun State University, Nigeria for their advice and moral support.

\section{References}

Adejumo SA, Togun AO, Adediran JA, Ogundiran MB (2011).In-situ remediation of heavy metal contaminated soil using Mexican sunflower (Tithonia diversifolia) and cassava waste composts. World Journal of Agricultural Sciences 7(2):224-233.

Aiyesanmi AF, Okoronkwo AE, Sunday OM (2012). Lead accumulation in Siam weed (Chromolaena odorata), Node weed (Synedrella nodiflora) and Water leaf (Talinum triangulare). Potential Phytoremediators Archives of Applied Science Research 4(1):360-371.

Audu AA, Lawal AO (2005). Variation in metal contents of plants in vegetable garden sites in Kano Metropolis. Journal of Applied Science and Environmental Management 10(2):105-109.

Blaylock MJ, Salt DE, Dushenkov S, Zakarova O, Gussman C, Kapulnik Y, Ensley BD, Raskin I (1997). Enhanced accumulation of $\mathrm{Pb}$ in Indian mustard by soil-applied chelating agents. Environmental Science \& Technology 31(3):860-865.

Blowes D (2002). Tracking hexavalent chromium in groundwater. Science 295:2024-2025.

Chan K (2003). Some aspects of toxic contaminants in herbal medicines Chemosphere 52:1361-1371.

Cho-Ruk K, Kurukote J, Supprung P, Vctayasuporn S (2006). Perennial plants in the phytoremediation of lead contaminated soils. Biotechnology 5(1):1-4.

Dada OE, Awotoye OO (2013). Assessment of the elemental depositions of Cadmium and Lead in two tropical medicinal plants. International Journal of Ecology and Environmental Studies 1(1):47-59.

Dzomba P, Chayamiti T, Togarepi E (2012). Heavy metal content of selected raw medicinal plant materials: Implication for patient health. Bulletin of Environment Pharmacology and Life Sciences 1(10):28-33.

FAO/WHO (1976). List of maximum levels recommended for contaminants by the joint FAO/WHO codex Alimentarias Commission. 2nd series, CAC/FAL 3:1-8.

Fitz WJ, Wenzel WW (2002). Arsenic transformation in the soilrhizosphere-plant system, fundamentals and potential application of phytoremediation. Journal of Biotechnology 99(3):259-278.

Henry JR (2000). An overview of the phytoremediation of Lead and Mercury. US Environmental Protection Agency Office of Solid Waste and Emergency Response Technology Innovation office Washington DC, EPA.

Huang JW, Chen J, Berti WR, Cunningham SD (1997). Phytoremediation of lead-contamination soil: role of synthetic chelates in lead phytoextraction. Environmental Science \& Technology 31(3):800-805.

Idu M, Onyibe HI (2007). Medicinal plants of Edo State, Nigeria. Research Journal of Medicinal Plant 1(2):32-41.

IITA (1982). Automated and semi-automated methods for soil and plant analysis. In: Poonam VR, Dirk AT (Eds). International Institute of Tropical Agriculture.

Jonathan SG, Olawuyi OJ, Aina DA, Odeniyi SO, Adediji IO, Ikhedia A (2012). Comparative studies on antifungal, anti-oxidant and 
294

phytochemical potential of Momordica charantia and Moringa oleifera. New York Science Journal 5(12):17-28.

Kabata-Pendias A (2010). Trace elements in soils and plants. CRC press.

Khan SA, Khan L, Hussain I, Marwat KB, Akhtar N (2008). Profile of heavy metals in selected medicinal plant. Pakistan Journal of Weed Science Research 14(1-2):101110.

Lane SD, Martin ES (1977). A histochemical investigation of lead uptake in Raphanussativus. New Phytologist 79:281-286.

Lokhande RS, Sathe CN (2003). Studies on industrial effluent with reference to heavy metals content. Asian Journal of Chemistry 15(1):335-338.

McBride MB (1994). Environmental chemistryof soils. Oxford University Press, New York pp:336-337.

McLaughlin MJ, Parker DR, Clark JM (1999). Metals and micronutrients-food safety issues. Field Crops Research Journal 60:143-163.

Mojiri A (2011). The potential of corn (Zea mays) for phytoremediation of soil contaminated with Cadmium and Lead.J Biol Environ Sci 5(13):17-22.

Nie JH, Liu XM, Wang QR (2004). Effects of nutrient elements on the lead uptake by hyperaccumulators. Ecology and Environment 13(3):306-309.

Nwachukwu CU, Umeh CN, Kalu IG, Okere S, Nwoko MC (2010). Identification and traditional uses of some common medicinal plants in Ezinihitte Mbaise LGA, Of Imo State, Nigeria. Report and Opinion 2(6):1.

Parsa DF, Bahreini-Nejad B, Safari-Sanjani AK, Kaboli MM (2007). Phytoremediation of lead with native rangeland plants in Irankoh polluted soils. Pajouhesh and Sazandegi 20:54-63.

Patra M, Bhowmik N, Bandopadhyay B, Sharma A (2004). Comparison of mercury, lead and arsenic with respect to genotoxic effects on plant systems and the development of genetic tolerance. Environmental and Experimental 52(3):199-223.

Paul A, Mitter K, Sen-Raychaudhuri S (2009). Effect of polyamines in in-vitro somatic embryogenesis in Momordica charantia L.. Plant Cell Tissue and Organ Culture 97:303-311.

Paul A, Raychaudhuri SS (2010). Medicinal uses and molecular identification of two Momordica charantia varieties: A review. Electronic Journal of Biology 6(2):43-51.

Rahimi M, Farhadi R, Mehdizadeh R (2013). Phytoremediation: using plants to clean up contaminated soils with heavy metals. International Journal of Agriculture: Research and Review 3(1):148-152.

Sharma B, Chhetri MK (2005). Monitoring of heavy metals in vegetables and soil of agricultural fields of Kathmandu Valley. Ecoprint: An International Journal of Ecology 12:1-9.

Sharma P, Dubey RS (2005). Lead toxicity in plants. Brazilian Journal of Plant Physiology 17(1):35-52.

Sofowora A (1993). Medicinal plant and traditional medicine in Africa. John Willey and Sons.
Sultana RS, Bari Miah MA (2003). In vitro propagation of Karalla (Momordica charantea Linn.) from nodal segment and shoot tip. Journal of Biological Sciences 3:1134-1139.

Sun YB, Zhou Q, Wang L, Liu W (2009). Cadmium tolerance and accumulation characteristics of Bidens pilosa $\mathrm{L}$. as a potential Cdhyperaccumulator.Journal of Hazardous Materials 161(2):808-814.

Sun YB, Zhou QX, Diao CY (2008). Effects of cadmium and arsenic on growth and metal accumulation of Cd-hyperaccumulator Solanum nigrum L. Bioresource Technology 99(5):1103-1110.

Tang YT, Rong-Liang, Qiu RL, Zenga JW, Ying RR, Yu FM, Zhou XY (2009). Lead, zinc, cadmium hyperaccumulation and growth stimulation in Arabis paniculata Franch. Environmental and Experimental Botany 66:126-134.

Taylor L (2002). Technical data report for bitter melon (Momordica charantia). Herbal Secrets of the Rainforest pp 1-103.

Wang HQ, Lu SJ, Yao ZH (2007). EDTA-enhanced phytoremediation of lead contaminated soil by Bidens maximowicziana. Journal of Environmental Sciences 19(12):1496-1499.

WHO (1998). Quality control methods for medicinal plant materials. World Health Organization Geneva pp 62-63.

WHO (2005). Quality control methods for medicinal plant materials. World Health Organization Geneva pp 3-70.

WHO (2007). Guidelines for assessing quality of herbal medicine. World Health Organization Geneva.

Yap CK, Mohd-Fitrim MR, Mazyhar Y, Tan SG (2010). Effects of metal contaminated soils on the accumulation of heavy metals in different parts of Centella asiatica: A laboratory study. Sains Malaysiana 39(3):347-352.

Zhang H, Dang Z, Zheng LC, Yi XY (2009). Remediation of soil cocontaminated with pyrene and cadmium by growing maize ( $Z e a$ mays L.). International Journal of Environmental Science \& Technology 6(2):249-258.

Zhuang P, Zou B, Li NY, Li ZA (2009). Heavy metal contamination in soils and food crops around Dabaoshan mine in Guagdong, China: Implication for human health. Environmental Geochemistry and Health 31(6):707-715. 